\title{
Reviews
}

RUSSIAN TRAVELLERS IN ALASKA

RUSSIAN EXPLORATION IN SOUTHWEST ALASKA; THE TRAVEL JOURNALS OF PETR KORSAKOVSKIY (1818) AND IVAN YA. VASILEV (1829). VanStone, James W. (editor). 1988. Fairbanks, University of Alaska Press (Rasmuson Library Historical Translation Series 4). $120 \mathrm{p}$, maps, soft cover. ISBN 0$912006-27-7$. US $\$ 15.00$ plus $\$ 1.50$ postage and packing.

This excellent series seeks to fill a major gap in the historiography of exploration of Arctic and sub-Arctic America: the work of Russians in Russian America. The present volume gives us an English version, by a very experienced translator, of two original journals of which microfilms are available at the University of Alaska; and translates also the instructions given to the writer of one of the journals by his superior, the general manager of the Russian American Company, a document recently published in Russian.

The longer account is by $P$. Korsakovskiy, a company employee, and describes his travels round the shores of Bristol Bay in 1818. The party travelled in baydarkas canoes with one, two or three hatches - and met many natives, with whom relations were generally good. The journal contains some useful information on anthropology and natural history. The second account, by I. Ya. Vasilev, another company man, concerns his journeys in the same general area ten years later. It is shorter and less informative than Korsakovskiy's, but is preceded by ten pages of interesting instructions from his much more knowledgeable superior, P. Ya. Chistyakov.

The texts are well annotated by Professor VanStone, who also writes a succinct and pertinent introduction. But the other editorial aid, maps, are rather less successful, some needing clearer distinction between land and sea and others taxing the eyesight. The translation reads smoothly, but, to pick a nit, kayur is surely a dog driver, not a 'displaced person doing forced labour in an artel'. (Terence Armstrong, Scott Polar Research Institute, University of Cambridge, Lensfield Road, Cambridge CB2 1ER UK.)

\section{MAN OF DESTINY}

THE NOOSE OF LAURELS: THE DISCOVERY OF THE NORTH POLE. Herbert, Wally. 1989. London, Hodder and Stoughton. $395 \mathrm{p}$, maps, hard cover. ISBN 0340-41276-3. £16.95.

The Encyclopaedia Britannica in its entry for Admiral Robert Edwin Peary describes him as 'usually credited' with the discovery of the North Pole on 6 April 1909, a clear hint at the controversy surrounding that historic claim. Did Peary prove conclusively that he had stood at latitude $90^{\circ} \mathrm{N}$ ? If so, had the victory perhaps been preempted by Frederick Cook's claim a year earlier? Maybe neither had been there. And so the battle has raged inconclusively over the years, fuelled by Peary's own obsessive secrecy concerning his field records and the subsequent reluctance of the family to make these records public. Now, at last, they have been made available to Wally Herbert, whose knowledge of the Arctic and empathy with Peary himself recommended him to the National Geographic Society as a properly qualified arbiter. Three years of researching the Peary archives have resulted in an engrossing account of the explorer's arctic expeditions and a fair delineation of his complex persona.

That Peary regarded himself as a man of destiny whose God-given purpose in life was to gain the North Pole for his country is well documented; what is less well-known, as the author makes so abundantly clear, is the ruthlessness of his methods. No other must be seen to steal his limelight. The challenge of his former friend and fellow explorer, Frederick Cook, and the consequent official enquiry as to his claim, nearly led to Peary's own undoing. For as Wally Herbert clearly demonstrates, 'Peary's need to reach the North Pole distracted him from his obligation as an explorer to observe and record'. A masterly analysis of Peary's field records reveals a suspiciously incomplete $\log$ clearly tinkered with after the event, a failure to check longitude for lateral ice drift, a failure to take observations for magnetic variation, and distances and speeds that seem barely credible. These and other incongruities lead the author to conclude that Peary failed to reach $90^{\circ} \mathrm{N}$ - and knowingly concealed the truth. The laurels and gold medals for which he hungered and which in most respects he so richly deserved, in the end destroyed him. This absorbing analysis of the man and his work, though it demolishes the central myth, still leaves him as essentially a hero, albeit a flawed one. (H. G. R. King, Scott Polar Research Institute, University of Cambridge, Lensfield Road, Cambridge CB2 1ER, UK.)

\section{IN SEARCH OF FRANKLIN}

THE JOURNAL OF ROCHFORT MAGUIRE 1852 1854: TWO YEARS AT POINT BARROW, ALASKA, ABOARD HMS PLOVER IN THE SEARCH FOR SIR JOHN FRANKLIN. Bockstoce, John (editor). 1988. London, The Hakluyt Society. Second Series, No 169.2 vols. $584 \mathrm{p}$, illustrated, hard cover. ISBN 0-904180-24-7.

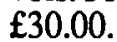

During the nineteenth-century search for the Northwest Passage, most voyages were made from Great Britain westward to Davis and Hudson straits, gateways to the supposed sea route to the Pacific. Activity focussed on the eastern parts of the North American Arctic rather than the western regions, mainly for logistical reasons. By the circuitous route around Cape Horn, Bering Strait was six or seven times farther from Britain than Davis Strait. But the distant Pacific approaches to the Northwest Passage assumed a new importance during the search for Sir John 